Pesq. Vet. Bras. 30(4):317-320, abril 2010

\title{
Distribution of collagen types I, III, and IV in gastric tissue of marmosets (Callithrix spp., Callitrichidae: Primates) ${ }^{1}$
}

\author{
Marcela F.V. de Mello ${ }^{2^{*}}$, Alcides Pissinatti $3,4,5$ and Ana M.R. Ferreira ${ }^{2}$
}

\begin{abstract}
Mello M.F.V., Pissinatti A. \& Ferreira A.M.R. 2010. Distribution of collagen types I, III, and IV in gastric tissue of marmosets (Callithrix spp., Callitrichidae: Primates). Pesquisa Veterinária Brasileira 30(4):317-320. Departamento de Patologia e Clínica Veterinária, Faculdade de Veterinária, Universidade Federal Fluminense, Rua Vital Brasil Filho 64, Niterói, RJ 24230-340, Brazil. E-mail: marcelafvmello@hotmail.com

Extracellular matrix (ECM) components such as fibrillar collagens play a fundamental role in wound repair and have also been studied in association with the gastric ulcer healing process in gastroenterology. Nevertheless, there have been no studies in the literature to date regarding the description and characterization of ECM components, neither in normal nor in injured gastric tissue of primate species. The objective of this study was to investigate the expression of gastric collagen types I, III, and IV in marmosets (Callithrix sp.). Histological specimens from the stomach of 6 Callithrix jacchus, 12 C. kuhli, and 12 C. geoffroyi were evaluated. The specimens were immunostained with anti-types I and III collagen polyclonal antibodies and anti-type IV collagen monoclonal antibody. Collagen types I and III were detected in the submucosa and lamina propria between the mucosal glands while collagen type IV was detected in the muscularis mucosae, muscular layers, blood vessels, and gastric mucosa between the mucosal glands. It is hoped that these findings can contribute to future studies on the gastric extracellular matrix components in primates and to comparative studies in the area of gastroenterology.
\end{abstract}

INDEX TERMS: Extracellular matrix, stomach, primates.

RESUMO.- [Distribuição dos colágenos tipo I, III e IV em tecido gástrico de sagüis (Callithrix spp., Callitrichidae: Primates).] Os componentes da matriz extra-celular (MEC), como os colágenos fibrilares, desempenham um papel fundamental no reparo de feridas, tendo sido estudados em gastroenterologia, em associação com a cicatrização da úlcera gástrica. No entanto, não há estudos até

\footnotetext{
${ }^{1}$ Received on February 6, 2009.

Accepted for publication on October 30, 2009.

2 Departamento de Patologia e Clínica Veterinária, Faculdade de Veterinária, Universidade Federal Fluminense (UFF), Rua Vital Brasil Filho 64, Niterói, RJ 24230-340, Brazil. "Corresponding author: Rua Iriquitiá 145, C-3, Jacarepaguá, Rio de Janeiro, RJ 22730-150, Brazil. E-mail: marcelafvmello@hotmail.com

${ }^{3}$ Centro de Primatologia do Rio de Janeiro (CPRJ), Fundação Estadual de Engenharia do Meio Ambiente (FEEMA), Estrada do Paraíso s/ n, Guapimirim, RJ 25940-000, Brazil.

${ }^{4}$ Centro Universitário Plínio Leite, Rua Ademar Ferreira Torres s/n, Itaboraí, RJ 24800-000, Brazil.

${ }^{5}$ Fundação Educacional Serra dos Órgãos, Av. Alberto Torres 111, Alto, Teresópolis, RJ 25964-004, Brazil.
}

o presente momento, que relatem a descrição e caracterização de componentes da MEC no tecido gástrico, quer seja normal ou com lesão, de espécies de primatas. O objetivo deste estudo foi investigar a expressão dos colágenos tipo I, III e IV no tecido gástrico de sagüis (Callithrix sp.). Foram avaliadas amostras do estômago de 6 Callithrix jacchus, 12 C. kuhli e 12 C. geoffroyi. As amostras foram submetidas à reação de imuno-histoquímica com anticorpos policlonais anti-colágenos tipo I e III e monoclonal anticolágeno tipo IV. Os colágenos tipo I e III foram detectados na submucosa e na lâmina própria da mucosa, entre as glândulas gástricas, enquanto que o colágeno tipo IV foi detectado na muscularis mucosae, nas camadas musculares, nos vasos sanguíneos e na camada mucosa, entre as glândulas gástricas. Estes achados poderão contribuir com estudos futuros relacionados aos componentes da MEC no tecido gástrico de primatas e com estudos comparativos na área da gastroenterologia.

TERMOS DE INDEXAÇÃO: Matriz extra-celular, estômago, primatas. 


\section{INTRODUCTION}

Multicellular animals possess various extracellular matrices, responsible for determining body shape and stability, organ structure, and a number of cellular activities (Timpl 1989).

The extracellular matrix (ECM) is formed by complex and intrincate networks within which molecules are precisely organized. These molecular networks determine the specific histoarchitecture of tissues and provide cells with biological information and a mechanical scaffold for adhesion and migration (Aumailley \& Gayraud 1998). The structural extracellular matrix molecules are collagens, noncollagenous glycoproteins, and proteoglycans (Aumailley \& Gayraud 1998). Type I, found in a variety of tissues, is the most abundant collagen. Many of the other fibril-forming collagens have a more selective tissue distribution. For example, the expression of type III collagen is observed in extensible connective tissues such as those found in the vascular system while the expression of type IV collagen is seen in basement membranes (Prockop \& Kivirikko 1995, Sato et al. 2007, Baba et al. 2008).

ECM plays an important role in wound repair (Mikami et al. 1994) not only by providing support for regenerating cells, but also by creating the appropriate environment for cellular interaction (Shahin et al. 1997). In this connection, other investigations have focused on the expression of ECM components in the stomach and their role in pathological gastric conditions (Gillensen et al. 1993, Shahin et al. 1997, Baba et al. 2007).

ECM of the gastric mucosa is composed of collagen, laminin, proteoglycan, elastin, fibronectin, and hyaluronic acid (Mori et al. 2003). Fibrillar collagens are especially important for the generation of wound strength in the peptic ulcer healing process. Furthermore, stimulation of the synthesis of collagen types I, III, and IV has been described in the gastric ulcerated areas of rats (Shahin et al. 1997). Matrix enzymes such as metalloproteinases are also associated with pathological conditions causing gastric injury as in the Helicobactersp. infection (Mori et al. 2003).

Although the elucidation of the molecular composition of these complex structures in human tissues has been rapidly developing via the use of a variety of molecular biology approaches, no studies describing or characterizing ECM components in the gastric tissue of the primate species were available for consultation. And because pathological conditions such as gastritis also occur among primate species (Dubois et al. 1991, Khanolkar-Gaitonde et al. 2000, Reindel et al. 1999), this study was conducted to analyze the expression of collagen types I, III, and IV in the gastric tissue of marmosets (Callithrix sp.).

\section{MATERIALS AND METHODS}

Animals. Thirty captive marmosets (6 Callithrix jacchus, 12 C. kuhli, and 12 C. geoffroyi, 11 males and 19 females, 2-15 years of age) had their stomachs used in this study. These animals were maintained in captivity at Centro de Primatologia do Rio de Janeiro (CPRJ) of Fundação Estadual de Engenharia do Meio Ambiente (FEEMA), in Guapimirim, RJ, Brazil, and died of natural causes at different times. This Brazilian Institution works with conservation of non-human primates according to the legal requirements of animal care and use. The animals had been provided a diet of commercial chow, fresh fruit, and water ad libitum and had no history of gastric disease. The marmosets were group-housed in large, airy, brick-work cages in the midst of the extant Atlantic Rain Forest. Necropsy was conducted in dead animals and their organs and carcasses were fixed in neutral-buffered $10 \%$ formalin.

Specimens. One specimen from fundic, corpus, and antral gastric regions was collected from each of the 30 stomachs and fixed in neutral-buffered, 10\% formalin, totalizing 90 specimens. These specimens were routinely processed in paraffin for light microscopy, and histological sections were produced for both hematoxylin-eosin (HE) and immunohistochemistry staining. The antibodies used for immunostaining were rabbit anti-types $I$ and III collagen polyclonal antibodies ( $n$ - 2150-0020, and no 21500100, respectively; Biogenesis Corp., Brazil), and mouse antitype IV collagen monoclonal antibody ("Clone CIV 22"; no M0785; DAKO Corp., Carpinteria, CA, USA).

Immunohistochemistry (IHC). Sections were deparaffinized, rehydrated, and treated with $6 \%$ hydrogen peroxidase solution for 30 minutes prior to heat-induced antigen retrieval (water bath at $96^{\circ} \mathrm{C}$ for 30 minutes in a sodium citrate buffer, $\mathrm{pH} 6.0$ ). After antigen retrieval, sections were incubated with a solution of milk and bovine albumin $\left(37^{\circ} \mathrm{C}, 30\right.$ minutes), followed by treatment with rabbit anti-type I or anti-type III collagen polyclonal antibodies (dilution of 1:200, overnight), or mouse anti-type IV collagen monoclonal antibody (dilution of 1:50, overnight). Sections were washed three times with Tris buffer prior to treatment with DAKO LSAB Link (no K0690, item no 002488; DAKO Corp.) for 30 minutes at room temperature. Sections were again washed three times with Tris buffer prior to treatment with DAKO LSAB HRP (no K0690, item no 002492; DAKO Corp.) for 30 minutes at room temperature. After cleansing with Tris buffer, sections were treated with Diaminobenzidine Tetrahydrochloride Substrate, Chromogen System (DAB, no K3468; DAKO Corp.) to brown stain a specific collagen. All sections were counterstained with hematoxylin. For negative controls, the primary antibody was omitted.

Immunostained sections were qualitatively evaluated with regard to the detection of collagen types I, III, and IV, which was confirmed by way of brown immunostaining. A descriptive analysis of the intensity and distribution of the three types of collagen was conducted. The immunostaining was considered intense when the color obtained was strongly brown e it was considered mildly when the brown color was pale. For all the 30 animals, one section from fundic, corpus, and antral gastric regions underwent light microscopy examination by two different examiners.

\section{RESULTS}

The stomach of all marmosets, including Callithrix jacchus, C. kuhli, and C. geoffroyi, showed the same histological aspects. The stomach wall consisted of four main layers: (1) mucosa, which presented a thin smooth muscle layer in its base - muscularis mucosae, (2) submucosa, (3) muscular layer, and (4) serous layer (Fig.1A-C). Collagen type I was intensely detected in the submucosa of all gastric specimen (Fig.2A). However, in some cases, the lamina 

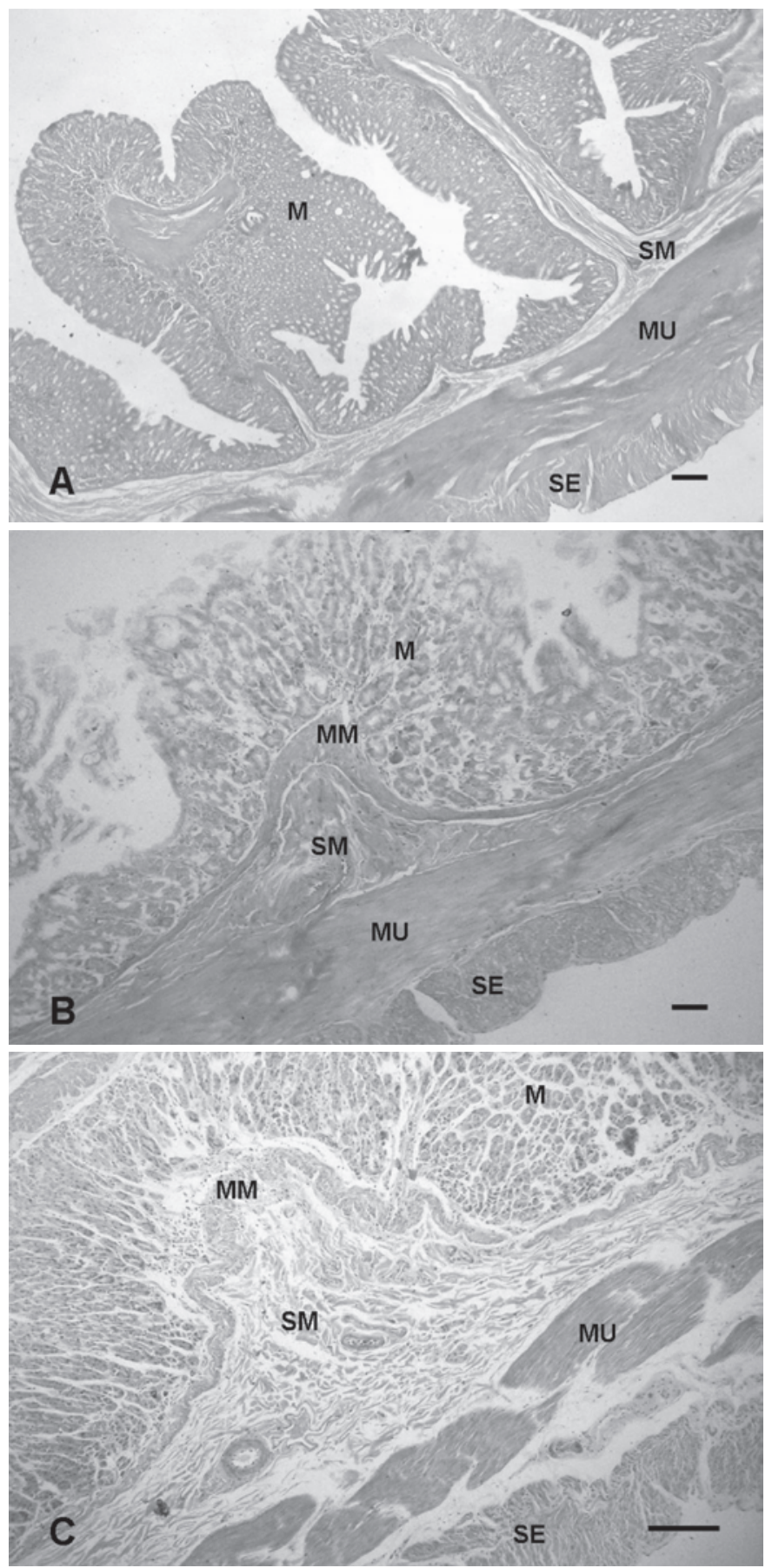

Fig.1. (A-C) HE stained sections from the gastric tissue of marmosets. $\mathrm{M}=$ mucosa; $\mathrm{MM}=$ muscularis mucosae; $\mathrm{SM}=$ submucosa; $\mathrm{MU}=$ muscular layer; $\mathrm{SE}=$ serous layer. Scale bar: $100 \mathrm{~mm}$.

propria between the mucosal glands was only mildly stained. Collagen type III was intensely detected in the submucosa of all gastric specimens (Fig.2B); and, in the majority of cases, intense staining was also present in the lamina propria between the mucosal glands. On the other hand, collagen type IV was intensely detected between the mucosal glands in gastric mucosa, in the blood vessels, and in the areas surrounding the smooth muscle cells in muscularis mucosae and muscular layers (Fig.2C).

No differences were found in the expression of collagen
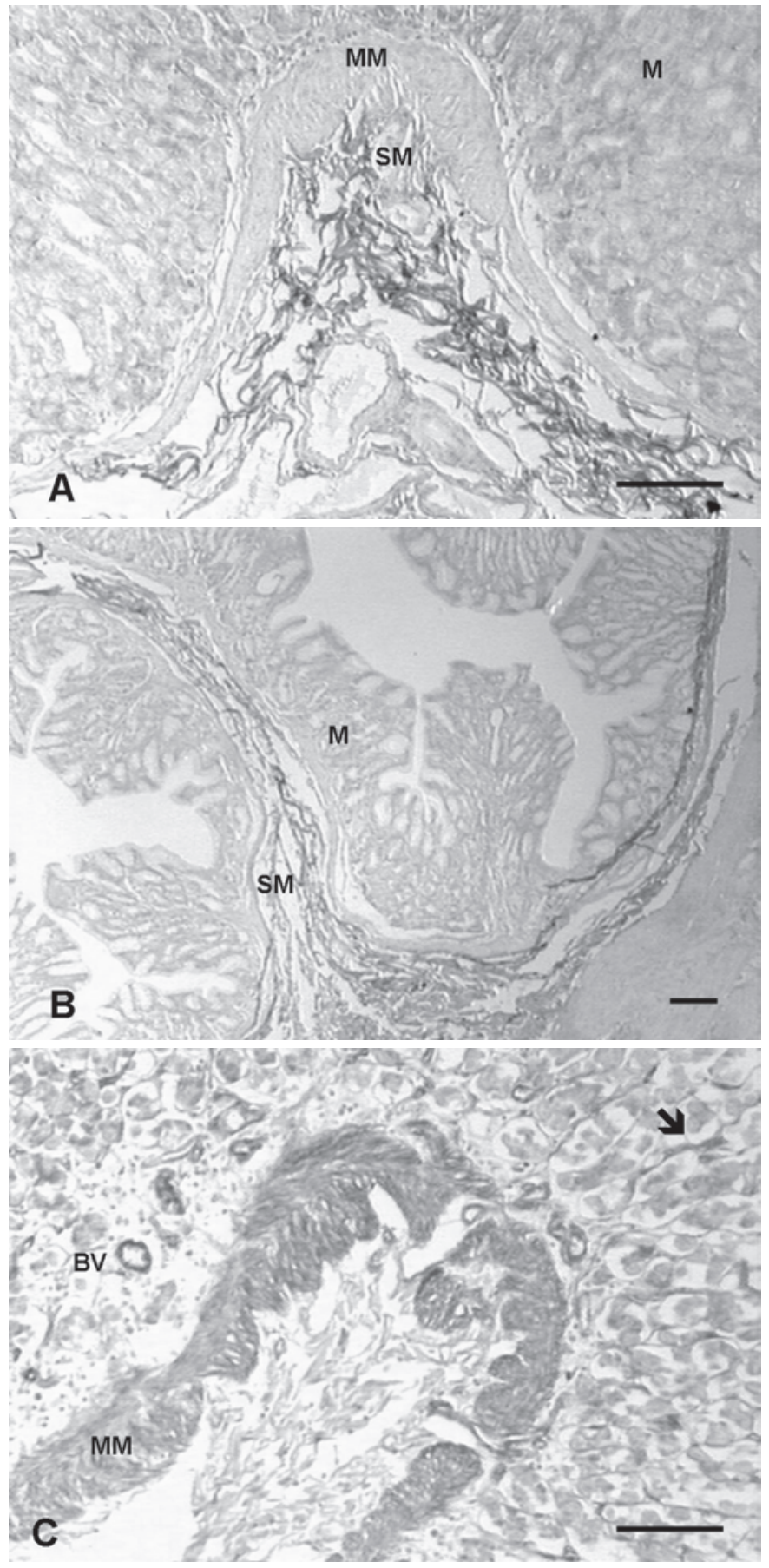

Fig.2. Immunostained sections from the gastric tissue of marmosets. (A) Collagen type I can be observed in the submucosa (SM). $\mathrm{M}=$ mucosa; $\mathrm{MM}=$ muscularis mucosae. (B) Collagen type III can be detected in the submucosa (SM), as well. $\mathrm{M}=$ mucosa. (C) Collagen type IV can be observed between the mucosal glands in gastric mucosa (arrow), in the blood vessels (BV), and in the areas surrounding the smooth muscle cells in muscularis mucosae (MM). Scale bar: $100 \mathrm{~mm}$. 
types I, III, or IV within the fundic, corpus, or antral gastric regions with regard to either presence or intensity. The results obtained were the same among the three Callithrix species studied as well as among males and females, and individuals from different ages. Specimens used as negative controls showed no immunoreaction.

\section{DISCUSSION AND CONCLUSIONS}

Fibrillar collagens, which are normal ECM components, were found to be involved in gastric lesions repair mechanisms in humans and rats (Gillensen et al. 1993, Shahin et al. 1997). The localization and distribution of collagen types I, III, and IV, assumed to be present in the gastric tissue of marmosets, were investigated.

In marmosets, the expression of collagen types I and III was intense in the submucosa of the gastric wall. In the lamina propria between the mucosal glands, however, collagen type I showed only mild staining, whereas collagen type III was detected by a more intense staining in the gastric sections. This distribution pattern was similar to the normal human gastric pattern described in one study in which collagen type III was more intensely expressed in the spaces between the gastric pits in the mucosa than collagen type I while type III exhibited the same staining intensity as collagen type I in the submucosa (Gillessen et al. 1993). Collagen types I and III were also detected by immunohistochemistry $(\mathrm{IHC})$ in the lamina propria between the mucosal glands and in the submucosa of normal rat gastric tissue (Shahin et al. 1997).

Collagen type IV, the most abundant structural component in basement membranes (Aumailley \& Gayraud 1998), was also detected in marmoset gastric tissue. In the present study, collagen type IV stained intensely not only around the mucosal glands and blood vessels within which basement membranes are present (Gillensen et al. 1993), but in the area circumventing the smooth muscle cells in the Muscularis mucosae and muscular layers as well.

Rat gastric tissues were also investigated and collagen type IV was detected in the lamina propria between the mucosal glands and the submucosa of normal stomachs in addition to the basement membranes of the gastric glands, blood vessels, and the Muscularis mucosae smooth muscle cells in ulcerated gastric areas (Shahin et al. 1997).

As previously mentioned, up to the publication of the present study, there was nothing available in the literature regarding the description and characterization of any ECM components in the gastric tissue of primates. Neither normal nor injured primate gastric tissue had yet been investigated about this subject. Then, there were no established patterns of normality accounting for the presence of collagen types I, III, or IV in these animals.
Since such pathological conditions as gastritis also occur in primates, the results observed in this study, concerning the expression of collagens in marmoset stomach, can be useful in attempting to obtain reliable information regarding the repair mechanisms of gastric lesions in non human primates.

Acknowledgements.- To the Postgraduate Program in Experimental Pathology (UFF) for its technical assistance, CAPES for support, FAPERJ (Proc. E-26/171.573/2000-APQ1), the American Zoo and Aquarium Association (AZA), the Greater Los Angeles Zoo Association (GLAZA), the Zoological Society of San Diego, the Golden Lion Tamarin Association, the Ministério Público Federal (RJ-Brasil), and IBAMA for their unfailing attention and support of the CPRJ-FEEMA conservation programs, as well as to Judy Grevan for editing the text.

\section{REFERENCES}

Aumailley M. \& Gayraud B. 1998. Structure and biological activity of the extracellular matrix. J. Mol. Med. 76:253-265.

Baba Y., Iyama K., Ikeda K., Ishikawa S., Hayashi N., Miyanari N., Honda Y., Sado Y., Ninomiya Y. \& Baba H. 2007. Differential expression of basement membrane type IV collagen a chains in gastric intramucosal neoplastic lesions. J. Gastroenterol. 42:874-880.

Baba Y., Iyama K., Ikeda K., Ishikawa S., Hayashi N., Miyanari N., Sado Y., Ninomiya Y. \& Baba H. 2008. The expression of type IV collagen a6 chain is related to the prognosis in patients with esophageal squamous cell carcinoma. Ann. Surg. Oncol. 15:555-565.

Dubois A., Tarnawski A., Newell D.G., Fiala N., Dabros W., Stachura J., Krivan H. \& Herman-Ackah L.M. 1991. Gastric injury and invasion of parietal cells by spiral bacteria in rhesus monkeys. Are gastritis and hyperchlorhydria infectious diseases? Gastroenterol. 100:884-891.

Gillessen A., Voss B., Rauterberg J. \& Domschke W. 1993. Distribution of collagen types I, III, and IV in peptic ulcer and normal gastric mucosa in man. Scand. J. Gastroenterol. 28:688-689.

Khanolkar-Gaitonde S.S., Reubish G.K., Lee C.K. \& Stadländer C.T.K.H. 2000. Isolation of bacteria other than Helicobacter pylori from stomachs of squirrel monkeys (Saimiri spp.) with gastritis. Dig. Dis. Sci. 45:272280.

Mikami H., Watanabe S., Hirose M. \& Sato N. 1994. Role of extracellular matrix in wound repair by cultured gastric mucosal cells. Biochem. Biophysic. Res. Commun. 202: 285-292.

Mori N., Sato H., Hayashibara T., Senba M., Geleziunas R., Wada A., Hirayama T. \& Yamamoto N. 2003. Helicobacter pylori induces matrix metalloproteinase-9 through activation of nuclear factor kB. Gastroenterol. 124:983-992.

Prockop D.J. \& Kivirikko K.I. 1995. Collagens: Molecular biology, diseases, and potentials for therapy. Ann. Rev. Biochem. 64:403-434.

Reindel J.F., Fitzgerald A.L., Breider M.A., Gough A.W., Yan C., Mysore J.V. \& Dubois A. 1999. An epizootic of lymphoplasmacytic gastritis attributed to Helicobacter pylori infection in cynomolgus monkeys (Macaca fascicularis). Vet. Pathol. 36:1-13.

Sato H., Naito I., Momota R., Naomoto Y., Yamatsuji T., Sado Y., Ninomiya Y. \& Ohtsuka A. 2007. The differential distribution of type IV collagen a chains in the subepithelial basement membrane of the human alimentary canal. Arch. Histol. Cytol. 70:313-323.

Shahin M., Gillessen A., Pohle T., Weber C., Schuppan D., Herbst H. \& Domschke W. 1997. Gastric ulcer healing in the rat: Kinetics and localisation of de novo procollagen synthesis. Gut 41:187-194.

Timpl R. 1989. Structure and biological activity of basement membrane proteins. Europ. J. Biochem. 180:487-502. 